\title{
ABSORPTIVITY OF PINE AND OAK PELLETS FOR PRODUCTION OF BIO AGGLOMERATES
}

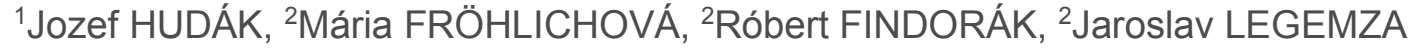 \\ 1ArcelorMittal Ostrava, Ostrava, Czech Republic, EU, Jozef.Hudak@arcelormittal.com \\ ${ }^{2}$ Technical University of Košice, Faculty of materials, metallurgy and recycling, Kosice, Slovak Republic, EU \\ maria.frohlichova@tuke.sk, robert.findorak@tuke.sk, jaroslav.legemza@tuke.sk
}

https://doi.org/10.37904/metal.2019.671

\begin{abstract}
The aim of this work is to understand how to manage biomass, either as a stand-alone fuel or in interaction with fossil fuel, and to help define optimal granulometry and fuel mix. A higher proportion of fine-grained particles in sawdust can lead to complications in agglomeration mixture. This work describes the process of absorptivity of oak and pine pellets with water of $25^{\circ} \mathrm{C}$, water of $60^{\circ} \mathrm{C}$, soapy water and industrial surfactant. The decisive factors influencing the absorption were the surface tension of the liquids, the type and granulometry of the materials. It has been confirmed that the use of liquids with a lower surface tension or surfactant value has resulted in higher material absorption values. The absorption values obtained are a basic data base that can be further studied and further developed. Based on the data obtained, it is possible to consider the appropriate granulometry of alternative fuels and the hypotheses to verify the fuels together with the iron ores and slag additives by pregranulation.
\end{abstract}

Keywords: Agglomerate, biomass, alternative fuels, technology, absorptivity

\section{INTRODUCTION}

The region of Slovakia is characterized by a significant amount of waste products from wood processing, which can be used in the metallurgical industry - in the production of agglomerate. The easy availability of biomass resources is its main advantage and predetermines it to be used in industrial applications [1-4]. The use of waste products or other types of biomass in the metallurgy with regard to the environment is given great attention [5-10]. Also interesting are the results dealing with the impact of the use of biomass on the quality of the agglomerate and the technological parameters of the agglomeration process [11-16]. The application of new materials to the process is linked to the assessment of the properties of the material, such as the shredding properties of sawdust [17]. The use of sawdust is associated with poorer permeability of the mixture, higher humidity and prolonged sintering time, which is also closely related to their granulometry. From the above, the sawdust was tested in the form of pellets, focusing on the absorption and swelling of the wood.

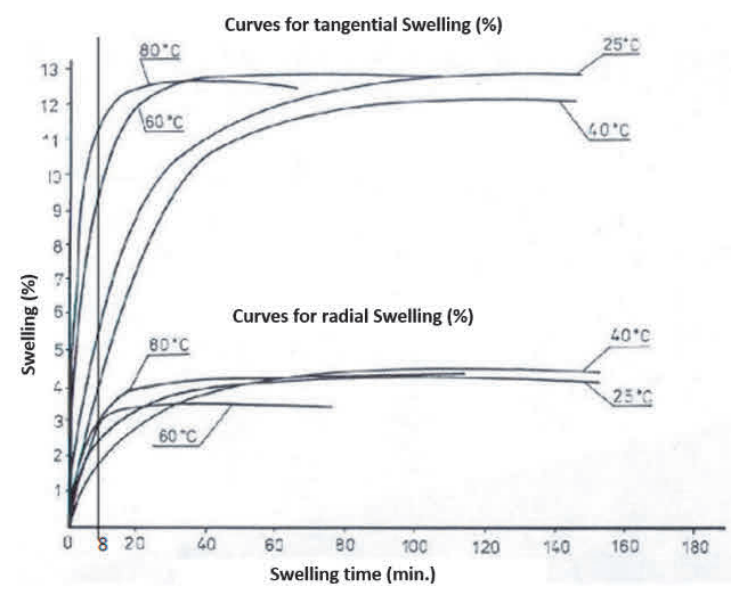

Figure 1 Influence of temperature on wood swelling [18] 
Increasing the moisture content of wood results in the growth of its size and hence its volume. This process is called wood swelling. It is most often expressed as a percentage, as a proportion of the change in size to the original value. The main factors influencing wood swelling are: wood species, moisture changes, density, temperature, or wood permeability. Different woods have different swelling values. Pine volumetric swelling is $12.1 \%$, tangential $7.7 \%$ and radial $4 \%$. For oak, the volume swelling is $12.2 \%$, tangentially $7.8 \%$, and radial swelling is $4 \%$. From these data, it is clear that the swelling of hardwoods is slightly higher compared to softwood [18]. The swelling of wood grows linearly with the density of the wood, so the higher the density of the wood, the higher the swelling values are achieved. The influence of temperatures on swelling values is shown in Figure 1. As can be observed, swelling of trees increases with temperature exponentially. At higher temperatures, the swelling process is also significantly shorter $[18,19]$.

When analyzing woody plants, the behavior of water in wood should also be considered. Wood permeability is a characteristic that characterizes the ability of wood to allow the movement of liquids in its structure. The paths for the movement of liquids, in the wood structure, are shown in Figure 2. It can be seen that with oak wood, a greater amount of water is absorbed into the material through the vessels and subsequently into the cells. With pinewood, water passes through tracheids, causing slower absorption and swelling. It can be assumed that due to the deformation in the production of pellets, the structure of trees is distorted $[18,19]$.

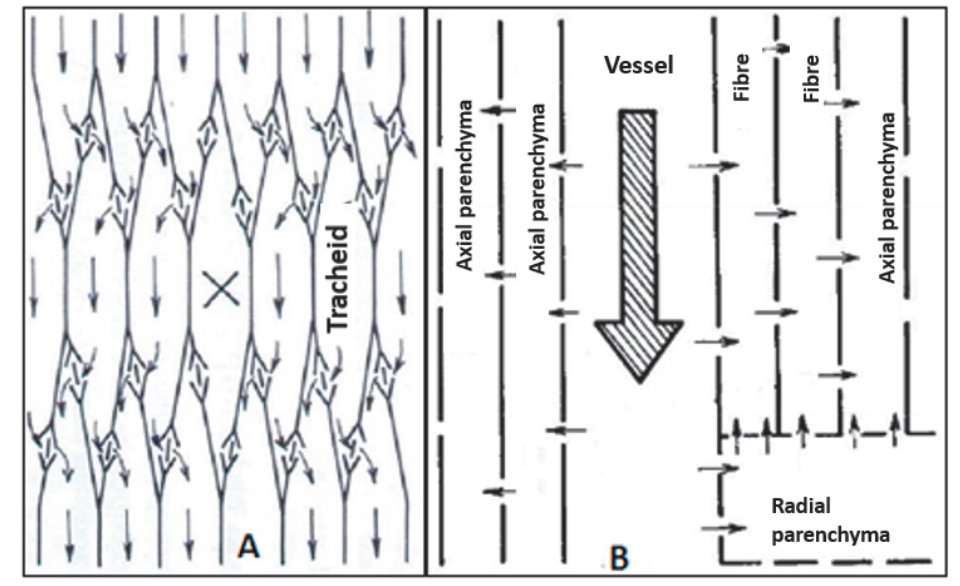

Figure 2 Axial wood permeability (A - Pine wood, B - Oak wood) [18]

\section{MATERIALS AND METHODS}

For laboratory tests, pine and oak pellets with the same chemical composition as the sawdust tested were provided [17]. The characteristic properties of pine and oak pellets are given in Table 1.

Table 1 The characteristic properties of pine and oak pellets [20]

\begin{tabular}{|c|c|c|c|c|c|c|c|}
\hline $\begin{array}{c}\text { Properties/ } \\
\text { Pellets }\end{array}$ & $\begin{array}{c}\text { Heat value } \\
(\mathrm{MJ} / \mathrm{kg})\end{array}$ & $\begin{array}{c}\text { Ash content } \\
(\%)\end{array}$ & Composition & $\begin{array}{c}\text { Water content } \\
(\%) \\
\end{array}$ & $\begin{array}{c}\text { Diameter } \\
(\mathrm{mm})\end{array}$ & $\begin{array}{l}\text { Length } \\
(\mathrm{mm})\end{array}$ & $\begin{array}{l}\text { Weight } \\
\left(\mathrm{kg} / \mathrm{m}^{3}\right)\end{array}$ \\
\hline Pine & 18.5 & 0.49 & \multirow{2}{*}{$\begin{array}{l}100 \% \text { natural } \\
\text { wood }\end{array}$} & 6.8 & 6.0 & 10.45 & 1120 \\
\hline Oak & 18.5 & 0.7 & & 7.3 & 6.8 & 10.20 & 1120 \\
\hline
\end{tabular}

The granulability of stand-alone pellets because of their format could not be done. The pellet absorption was carried out with 4 liquid-water at $20^{\circ} \mathrm{C}$ and $60^{\circ} \mathrm{C}, 1 \%$ soap solution and industrial surfactant [17]. Absorption and pellet swelling tests were performed as follows: pellets of approximately the same length were selected. Pine pellets were about $25.5 \mathrm{~mm}$ in length (average length $25.96 \mathrm{~mm}$, standard deviation 0.42 ) and their average weight was $0.74 \mathrm{~g}$ (SD 0.03). The oak pellets were about $20 \mathrm{~mm}$ long (average length $19.65 \mathrm{~mm}, \mathrm{SD}$ 
0.27 ) and their average weight was $1.09 \mathrm{~g}$ (SD 0.08). Subsequently, glass containers filled with the appropriate liquid were prepared. The pellets were placed in a vessel and the time was monitored. Intervals of 2, 4, 6 and 8 minutes were selected for pellet absorption. When time was reached, the pellets were removed from the liquid of the liquid water from the surface. Subsequently, the pellets were weighed and their lengths measured.

\section{RESULTS AND DISCUSSION}

The results of absorption and swelling of pine and oak pellets are given in Table 2 and Table 3.

Table 2 The results of absorption and swelling of pine pellets

\begin{tabular}{|c|c|c|c|c|c|c|c|c|c|c|c|c|c|c|c|c|}
\hline \multirow{2}{*}{$\begin{array}{c}\text { Pine } \\
\text { Time (min.) }\end{array}$} & \multicolumn{4}{|c|}{ Water $20^{\circ} \mathrm{C}$} & \multicolumn{4}{|c|}{ Soapy water (1\%) } & \multicolumn{4}{|c|}{ Water $60^{\circ} \mathrm{C}$} & \multicolumn{4}{|c|}{ Tenside } \\
\hline & 2 & 4 & 6 & 8 & 2 & 4 & 6 & 8 & 2 & 4 & 6 & 8 & 2 & 4 & 6 & 8 \\
\hline Sample no. & 1 & 2 & 3 & 4 & 5 & 6 & 7 & 8 & 9 & 10 & 11 & 12 & 13 & 14 & 15 & 16 \\
\hline m $1(g)$ & 0.77 & 0.73 & 0.76 & 0.72 & 0.78 & 0.75 & 0.75 & 0.80 & 0.78 & 0.75 & 0.72 & 0.71 & 0.74 & 0.73 & 0.69 & 0.70 \\
\hline m 2 (g) & 1.74 & 2.06 & 2.04 & 2.06 & 1.00 & 1.81 & 2.17 & 2.22 & 4.19 & 4.07 & 3.87 & 3.93 & 2.29 & 2.39 & 2.57 & 2.81 \\
\hline$\Delta \mathrm{m}(\mathrm{g})$ & 0.97 & 1.33 & 1.28 & 1.34 & 0.22 & 1.06 & 1.42 & 1.42 & 3.41 & 3.32 & 3.15 & 3.22 & 1.55 & 1.66 & 1.88 & 2.11 \\
\hline $\begin{array}{c}\text { Seelling up } \\
(\%)\end{array}$ & 126.0 & 182.2 & 168.4 & 186.1 & 28.2 & 141.3 & 189.3 & 177.5 & 437.2 & 442.7 & 437.5 & 453.5 & 209.5 & 227.4 & 272.5 & 301.4 \\
\hline I1 (mm) & 26.0 & 25.5 & 25.5 & 26.1 & 26.8 & 26.4 & 26.1 & 26.5 & 26.5 & 26.2 & 25.5 & 25.4 & 26.0 & 25.5 & 25.5 & 25.4 \\
\hline I 2 (mm) & 28.5 & 29.8 & 30.4 & 30.0 & 29.0 & 28.6 & 28.2 & 29.0 & 34.5 & 39.1 & 34.0 & 32.0 & 31.1 & 28.5 & 27.6 & 32.2 \\
\hline$\Delta \mathrm{I}(\mathrm{mm})$ & 2.5 & 4.3 & 4.9 & 3.9 & 2.2 & 2.2 & 2.1 & 2.5 & 8.0 & 12.9 & 8.5 & 6.6 & 5.1 & 3.0 & 2.1 & 6.8 \\
\hline $\begin{array}{c}\text { Swelling up } \\
(\%)\end{array}$ & 9.6 & 16.9 & 19.2 & 14.9 & 8.2 & 8.3 & 8.0 & 9.4 & 30.2 & 49.2 & 33.3 & 26.0 & 19.6 & 11.8 & 8.2 & 26.8 \\
\hline
\end{tabular}

Table 3 The results of absorption and swelling of oak pellets

\begin{tabular}{|c|c|c|c|c|c|c|c|c|c|c|c|c|c|c|c|c|}
\hline Oak & \multicolumn{4}{|c|}{ Water $20^{\circ} \mathrm{C}$} & \multicolumn{4}{|c|}{ Soapy water (1 \%) } & \multicolumn{4}{|c|}{ Water $60^{\circ} \mathrm{C}$} & \multicolumn{4}{|c|}{ Tenside } \\
\hline Time (min.) & 2 & 4 & 6 & 8 & 2 & 4 & 6 & 8 & 2 & 4 & 6 & 8 & 2 & 4 & 6 & 8 \\
\hline Sample no. & 1 & 2 & 3 & 4 & 5 & 6 & 7 & 8 & 9 & 10 & 11 & 12 & 13 & 14 & 15 & 16 \\
\hline m 1 (g) & 1.22 & 1.14 & 1.14 & 1.09 & 1.02 & 1.13 & 1.06 & 1.04 & 1.16 & 1.09 & 0.98 & 1.04 & 0.99 & 0.98 & 1.16 & 1.25 \\
\hline m 2 (g) & 1.54 & 4.22 & 5.50 & 5.17 & 4.20 & 4.20 & 5.11 & 4.72 & 5.38 & 4.72 & 5.04 & 6.00 & 2.78 & 4.34 & 4.28 & 3.53 \\
\hline$\Delta \mathrm{m}(\mathrm{g})$ & 0.32 & 3.08 & 4.36 & 4.08 & 3.18 & 3.07 & 4.05 & 3.68 & 4.22 & 3.63 & 4.06 & 4.96 & 1.79 & 3.36 & 3.12 & 2.28 \\
\hline $\begin{array}{c}\text { Seelling up } \\
(\%)\end{array}$ & 26.2 & 270.2 & 382.5 & 374.3 & 311.8 & 271.7 & 382.1 & 353.8 & 363.8 & 333.0 & 414.3 & $\begin{array}{c}476 . \\
9\end{array}$ & 180.8 & 342.9 & $\begin{array}{c}269 . \\
0\end{array}$ & 182.4 \\
\hline I $1(\mathrm{~mm})$ & 20.2 & 19.5 & 19.4 & 20.0 & 19.5 & 19.8 & 19.4 & 19.4 & 19.5 & 19.9 & 19.5 & 19.3 & 19.5 & 19.5 & 20.0 & 20.0 \\
\hline I $2(\mathrm{~mm})$ & 27.9 & 30.8 & 32.9 & 29.8 & 30.5 & 29.9 & 33.2 & 32.4 & 31.9 & 30.9 & 32.0 & 34.8 & 34.8 & 30.8 & 32.5 & 32.2 \\
\hline$\Delta \mathrm{I}(\mathrm{mm})$ & 7.7 & 11.3 & 13.5 & 9.8 & 11.0 & 10.1 & 13.8 & 13.0 & 12.4 & 11.0 & 12.5 & 15.5 & 15.3 & 11.3 & 12.5 & 12.2 \\
\hline $\begin{array}{c}\text { Swelling up } \\
(\%)\end{array}$ & 38.1 & 57.9 & 69.6 & 49.0 & 56.4 & 51.0 & 71.1 & 67.0 & 63.6 & 55.3 & 64.1 & 80.3 & 78.5 & 57.9 & 62.5 & 61.0 \\
\hline
\end{tabular}

These data suggest that pine pellets were best absorbed in water at $60{ }^{\circ} \mathrm{C}$. Compared to the industrial surfactant, these values were approximately 1.5-2 fold higher. At a shorter absorption time ( 2 and $4 \mathrm{~min}$ ), the sawdust was least absorbent in $1 \%$ soap solution, at 6 and 8 minutes in room temperature water (Figure 3 ). For all liquids except $60^{\circ} \mathrm{C}$, an increase in pellet weight over time was observed. Using water at $60^{\circ} \mathrm{C}$, a slight decrease in weight was observed over time, which can be explained by reaching a saturation state within 2 minutes. The weight loss could occur due to a higher water temperature and subsequent dissolution of the wood components e.g. lignin, or other components released during compression. Another explanation is to provide a higher water temperature to the wood components associated with the release of oils and other 
hydrophobic components. This results in a change in the behavior of the liquid and, in conjunction with the effect of the wood structure, water is released from the woody plant structure.

The axial swelling values correlate with the absorption values. The highest values, on average $34.7 \%$, were obtained at $60{ }^{\circ} \mathrm{C}$. Almost half the lower values were found using surfactant- $16.6 \%$ and water $20{ }^{\circ} \mathrm{C}-15.2 \%$. The lowest swelling values were recorded using $1 \%$ soapy water $-8.5 \%$.

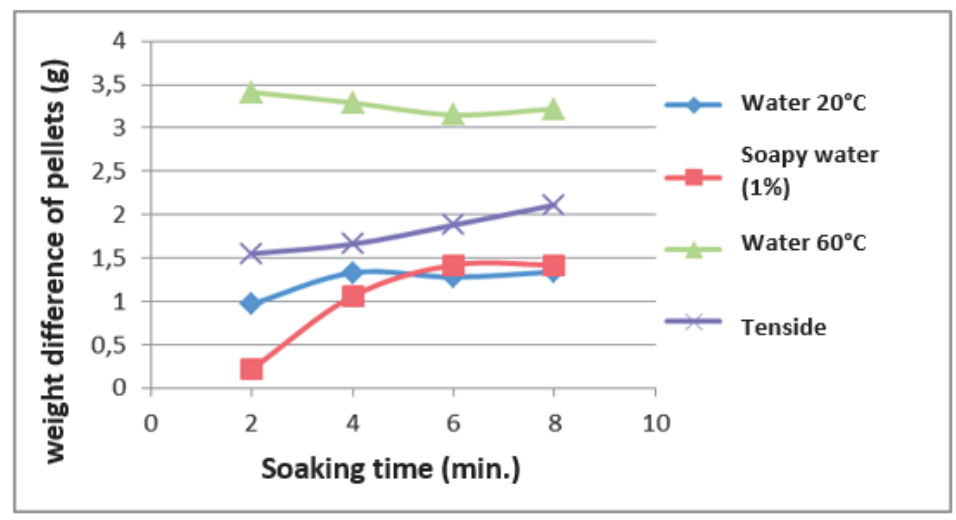

Figure 3 Absorption of pine pellets

Figure 4 shows the different values of the absorption of oak pellets. Oak pellets, like pine, were best absorbed in warm water. The pellets were in 6 resp. 8 minutes least absorbent in industrial surfactant. In the 4 minute liquid treatment, its soaked amount was almost identical for all samples. When comparing both woods, the soaking values of the oak pellets are approximately 1.5- fold higher compared to pine pellets.

Significantly higher differences were found when comparing the axial swelling of the pellets. The highest average values were obtained with water of $60{ }^{\circ} \mathrm{C}-65.8 \%$. Almost identical values were found using surfactants $-65 \%$ and using $1 \%$ soap water $-61.4 \%$. The lowest swelling values were recorded using water at $20{ }^{\circ} \mathrm{C}-53.7 \%$.

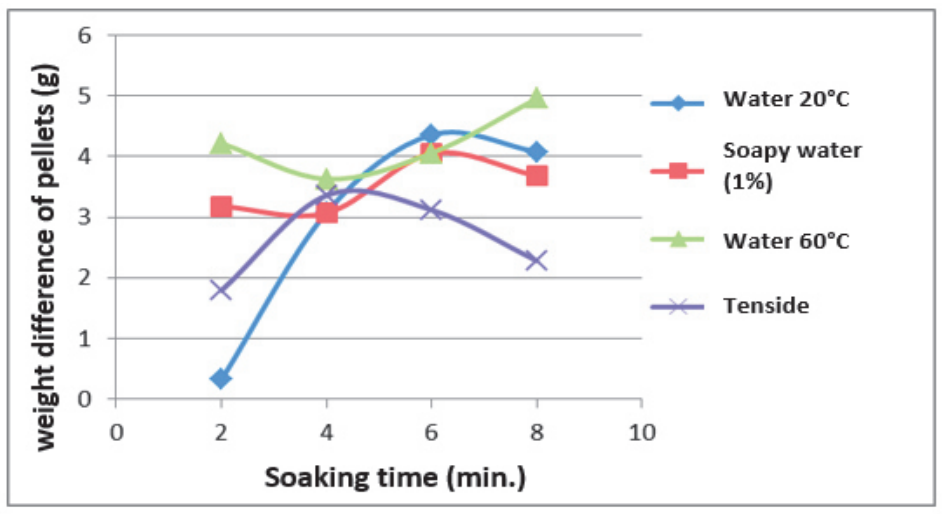

Figure 4 Absorption of oak pellets

As can be seen in Figure 5A, the sample that was in the water of $60^{\circ} \mathrm{C}$ disintegrated, with a significant change in shape and volume compared to the original sample. Pellets that have been soaked in water, respectively. In the soap solution, showed the smallest changes in shape and volume relative to the original sample. The oak pellets were characterized by the fact that by the action of liquids there was a significant destruction of the sample against the original sample, which is related to their structure (Figure 5B). It was difficult to manipulate the specimens during the soak and at the set time because they were not compact. Therefore, measuring the change in pellet length after soaking was difficult. In both monitored woods, the wood moisture increased to 
increase swelling in all directions. From the above data, it is clear that the swelling of hardwoods is significantly higher than the swelling of the softwood.
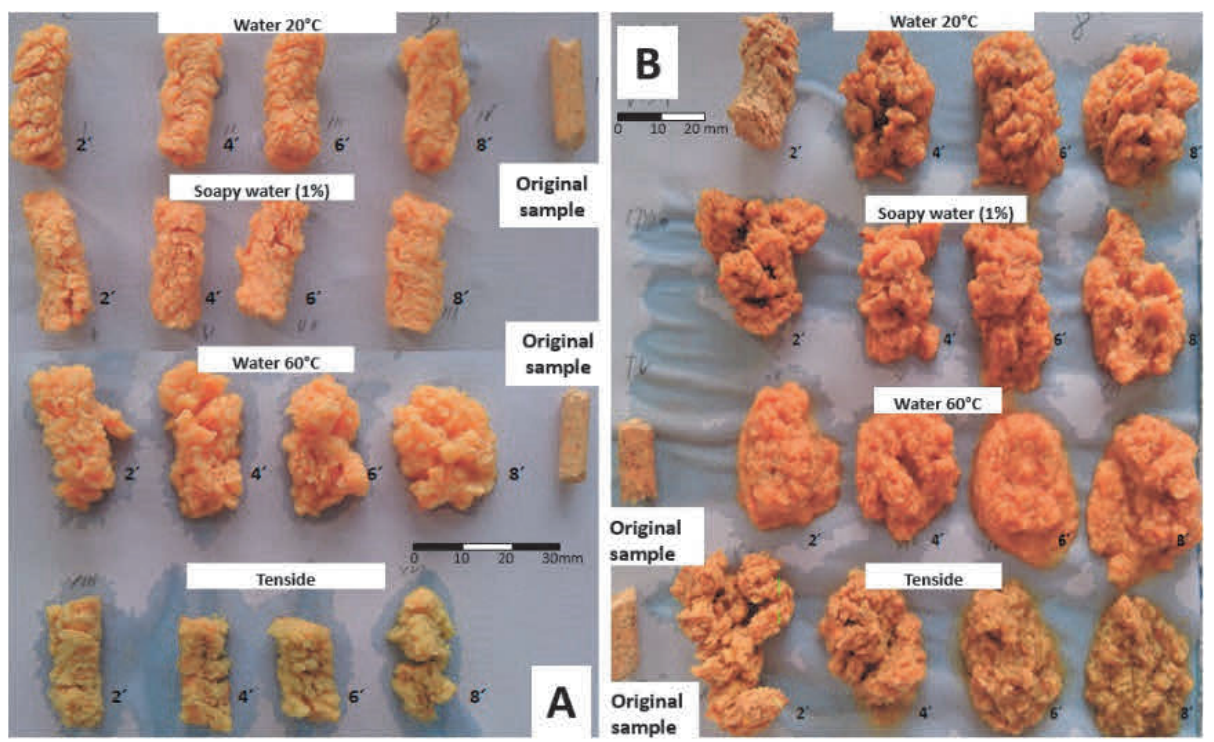

Figure 5 Comparison of absorption of pellets (A - pine, B - oak)

It is a dense material formed by mechanical action and heat release at a pressure of about $150 \mathrm{MPa}$. The effect of surfactant on swelling has been shown to a lesser extent. Substantially better materials were absorbed by warm water. The increase in pressure caused the lignin, which served as a binder, to be expelled from the woody structure, resulting in better hydrophilicity conditions, as it is largely influenced by cellulose and hemicellulose. Based on these data, it is possible to justify higher pellet swelling values with $60^{\circ} \mathrm{C}$ water.

Due to the hot water, the material is heated and the mold is disintegrated. From these data, it can be assumed that the swelling of sawdust from hardwood (oak) due to the diameter of the vessels to tracheids and the way of passing the liquid (water) through the structure was less affected by the deformation of the pellet molding structure than the swelling of sawdust of softwood (pine). Along with a higher pellet density and a lower water surface tension value of $60^{\circ} \mathrm{C}$, these effects have resulted in higher oak pellet swelling values.

\section{CONCLUSION}

The pellet absorption and swelling values obtained are a basic data base that can be further studied and further developed. Based on the data obtained, it is possible to consider the appropriate granulometry of alternative fuels, or to consider a combination of alternative fuels and hypotheses to verify by pelletizing the fuels together with the ore and pelletizers by pre-casting.

These findings correspond to the capillary absorption and granulability data of pine and oak sawdust. Pine sawdust is less absorbent than oak, which is confirmed by the above experiments, based on the amount of liquid absorbed. In terms of liquids, there is also a penetration of values from the capillary scavenging experiments. The best results were achieved by the action of hot water and industrial surfactant, while the pellets were absorbed to a lesser extent with water and soap solution.

\section{ACKNOWLEDGEMENTS}

This work was supported by Slovak Research and Development Agency (APVV), Slovak Republic, No. APVV-16-0513 and Slovak research and development agency (SRDA), Slovak Republic, No. VEGA1/0847/16. 


\section{REFERENCES}

[1] MONTIANO, María de Garabandal, DÍAZ-FAES, Elvira, BARRIOCANAL, Carmen and ALVAREZ, Ramón. Influence of biomass on metallurgical coke quality. Fuel. 2014. vol. 116, no. 1, pp. 175- 182.

[2] MAŠLEJOVÁ, A. Utilization of biomass in ironmaking, In: Metal 2013: 22th International Conference Metallurgy and Materials. Ostrava: TANGER, 2013, pp. 38-43.

[3] JANDAČKA, Jozef, MALCHO, Milan and MIKULÍK, Marian. Biomasa jako zdroj energie. 1st ed. Žilina: GEORG, 2007. $\mathrm{p} 78$.

[4] JANDAČKA, Jozef, NOSEK, Radovan, KADÚCHOVÁ, Katarína and KOLKOVÁ, Zuzana. Využitie rastlinnej biomasy v energetike. 1st ed. Žilina: GEORG, 2011. p 120.

[5] LEŠKO, Jaroslav, HUDÁK, Jozef and SEMANOVÁ, Zuzana. Impact of Biofuel in Agglomeration Process on Production of Pollutants Science of Sintering. 2017. vol. 49, no. 2, pp. 159-166.

[6] LEŠKO, J., LEGEMZA, J., HUDÁK, J., FRÖHLICHOVÁ, M. and FINDORÁK, R. Influence of pine and oak wood sawdust addition in the production of iron ore sinter on the environment. In:SGEM 2015: 15th International Multidisciplinary Scientific Geoconference, Science and Technologies in Geology, Exploration and Mining. Sofia. STEF92 Technology, 2015. pp. 629-636.

[7] NORGATE, Terry and LANGBERG, David. Environmental and economic aspects of charcoal use in steelmaking. ISIJ International. 2009. vol. 49, no. 4, pp. 587-595.

[8] OOI, Tze Chean, THOMPSON, Dennis, ANDERSON, David R., FISHER, Ray, FRAY, Trevor and ZANDI, Mohammad. The effect of charcoal combustion on iron-ore sintering performance and emission of persistent organic pollutants. Combustion and Flame. 2011. vol. 158, no. 5, pp. 979 - 987.

[9] GAN, Min, FAN, Xiaohui, CHEN, Xuling, JI, Zhiyun, LV, Wei, WANG, Yi, YU, Zhiyuan and JIANG, Tao. Reduction of Pollutant Emission in Iron Ore Sintering Process by Applying Biomass Fuels. Isij International. 2012. vol. 52, no. 9, pp. 1574-1578.

[10] QIN, Linbo, HAN, Jun, YE, Wei, ZHANG, Shun, YAN, Qiangu and YU, Fei. Characteristics of Coal and Pine Sawdust Co-carbonization. Energy Fuels. 2014. vol. 28, no. 2, pp. 848-857.

[11] CHEN, Gang and LEUNG, Dennis Y. C. Experimental Investigation of Biomass Waste, (Rice Straw, Cotton Stalk, and Pine Sawdust), Pyrolysis Characteristics. Energy Sources. 2003. vol. 25, no. 4, pp. 331-337.

[12] UMADEVI, T., DEODHAR, A. V., KUMAR, S., GURURAJ PRASAD, C. S. and RANJAN, M.. Influence of coke breze particle size on quality of sinter. Ironmaking and Steelmaking. 2008. vol. 35, no. 8, pp. 567 - 574.

[13] HUDÁK, J., FRÖHLICHOVÁ, M., LEGEMZA, J., FINDORÁK, R. and LEŠKO, J. Quality and technological parameters of agglomerateswith oak and pine sawdust as a replacement fuel. In: SGEM 2015: 15th International Multidisciplinary Scientific Geoconference, Science and Technologies in Geology, Exploration and Mining. Sofia. STEF92 Technology, 2015. pp. 667-673.

[14] ZANDI, Mohammad, MARTINEZ-PACHECO, Maria and FRAY, Trevor. Biomass for iron ore sintering. Minerals Engineering. 2010. vol. 23, no. 14, pp. 1139-1145.

[15] OOI, Tze Chean, ARIES, Eric, EWAN, Bruce, C.R., THOMPSON, Dennis, ANDERSON, David R., FISHER, Ray, FRAY, Trevor and TOGNARELLI, Donna. The study of sunflower seed husks as a fuel in the iron ore sintering process. Minerals Engineering. 2008. vol. 21, no. 2, pp. 167-177.

[16] LOVEL, Roy, VINING, Keith R. and DELL'AMICO, Mark. Iron ore sintering with charcoal. Mineral Processing and Extractive Metallurgy. 2007. vol. 116, no. 2, pp. 85 - 92.

[17] HUDÁK, Jozef, LEŠKO, Jaroslav, SEMANOVÁ, Zuzana, FRÖHLICHOVÁ, Mária, FINDORÁK, Róbert and LEGEMZA, Jaroslav. Evaluation of granulability and absorbtivity of biomass in agglomeration mixture. Journal of Central South University. 2017. vol. 24, no. 10, pp. 2260-2265.

[18] KÚDELA, Jozef. Vlastnosti dreva. [online]. 2013. [viewed 2019-03-17]. Available from: http://www.vos.volyne.cz/tu/soubory/fyz vlast.pdf

[19] GRAY, V. R.. Wetting, adhesion and penetration of surface coatings on wood. Journal of the Oil \& Colour Chemists' Association. 1961. vol. 44, no. 1, pp. 756-786.

[20] Technické údaje peliet. [online]. 2019. [viewed 2017-03-19]. Available from: https://www.ondrusek.sk/sk/peletybrikety/pelety/svetle 